\title{
Self. Propagating \\ a strategy of encounter
}

\section{GABRIELLE LORRAINE FLETCHER}

UNIVERSITY OF NEWCASTLE

$-1$

It starts out almost like every Saturday.

The stench of the goats next door is dispersed a little today because the Old Lady has milked them early and they are grazing at the bottom of the vacant lot. Normally they are near your bedroom window. You would slide the window shut to glaze your interior.

But today the curtains flutter slightly into late afternoon. You are reading Rousseau. Your father mows the grass. Your mother is cooking relish. Your brother is asleep.

The mower idles. Cogs down to a terse nothing. You put your book down, roll off the bed and close the door. Softly. You wait. Wait then catch your breath. Hold. Discipline your body into nerve-end flex. You clutch the creep.

ISSN 1837-8692

Cultural Studies Review 2015. @ 2015 Gabrielle Lorraine Fletcher. This is an Open Access article distributed under the terms of the Creative Commons Attribution 4.0 Unported (CC BY 4.0) License

(https://creativecommons.org/licenses/by/4.0/), allowing third parties to copy and redistribute the material in any medium or format and to remix, transform, and build upon the material for any purpose, even commercially, provided the original work is properly cited and states its license. 
Size eight-and-a-half Mongrel Oil Kip leather elastic-sided safety boots bump the bottom of the stairs. One. Two three. Your father beats the dirt and grass out of the rubber tread. Seven slighter shuffles. Then one, two, and three purging rips across ribbed matting outside the backdoor.

The squeal of the fly screen makes you spring. Three-step hustle to your bed. Make the Doona covers yawn, shove yourself under. Conceal your being. Cup your hands behind your head, stare at the ceiling.

Last week you were reading John Kennedy O'Toole. Your father was weeding the vegetable patch. Your mother made a quince tart. Your brother was asleep. The goats smelled bad.

Your father growls as he nears your door.

'Are you bastards still asleep?'

You close your eyes.

Hear him open your door. Poke his muzzle in.

Your father makes a game of his intrusion. Rattles the doorknob to imply departure. But you know the tiny arcing egress rub across the carpet.

You stay sealed.

You are more cunning in the counter-point. He is impatient, and suspicious of your concepts.

He snorts. Closes your door. Goes to spy on your brother.

You open your eyes in victory. Maybe you might drive away when you are old enough to get your licence. Sing on the moon. Or get a husband and two of your own children. Make them blonde and rewrite your mother with a happy ending. Find love, make yourself something, go to university. Even though he says you're a useless girl. You will free yourself with knowing. Things. Like a lubricious captive moth, it flickers. You close your eyes once more, and float the charge. Float. Float then drown. Sink.

Saturday night is always the same.

Your father drinks. For outside sweat. Inside habit. Your mother cooks. Oily fish and chips. Seedy Sunday antidote. Your brother is revived to eat.

You are reading Oodgeroo Noonuccal. You will stay in your room until ten. When your mother and brother retreat to their spaces, your stretch begins. 
You leave your room, close your door. Enter the lounge room. Take an audit of your father's empty cans, to gauge how full he is. You sit and listen to his drunken rant.

How hard it is. How much he tries. How being a black fulluh is shameful. How much we take. How much he hates. Us.

By eleven he is dangerous, getting hard to manage. You urge oily fish and chips upon him. Try and hasten him to go to sleep. Douse his abusive sparks with equal repetition.

That it's alright. That he is decent. That we never say that we are licked by tar. That it is our fault. Promise that we love. Him.

You are tired from the front-line dance. Old manoeuvres, always newly up to you. Somehow you were born beyond a child's brief. A freshly ancient sentry.

Eleven-thirty. Your father is eating his oily fish and chips. He doesn't notice that they look like contorted Pompeii relics. He tastes nothing. Ten minutes and you can box him up. Tidy this part of the night. You want to scream. Savage him with truth. But if you are too obvious, the wire will snap. So you act. Patient.

Finally he enters the bedroom he shares with your mother. You turn off the lights. You open your door. Sit on your bed. Eyes darting in the black, dilated for signs.

You wait for your mother's voice.

You hope she will say 'Hurry up'. It's safer for her. You will slither out to the lounge room and steal one of your father's cigarettes. Go to the backdoor and ease out onto the steps. Smoke by the stars. Blow strung up fumes.

When you are finished, he will be too. You don't want to hear them. It's not right. It's a loveless discharge. Human pulp. You watch for the bathroom light to go on. That will be your mother, mopping up. But at least the horror has reached end point. The night is over, and you can get back to your room discreetly and read.

Tonight you hear your mother-

'Get off. You're too pissed.'

You flash with rage that she has made it gruelling. This will take longer than a cigarette. Be harder than a stain to clean.

You hear your father- 
'I'm not pissed. You want it. Don't make me beg.'

You stand. Move to your door. Your fingers clip onto the door frame.

Your mother-

'I said no.'

You edge along the bookcase. Stand at their door. Hyper-aroused.

Your father-

'Prick tease. Cunt. Slut.'

You thump the wall. To splice. Remind.

Then your mother pleads with you-

'Go to bed, love. I'm alright.'

Your father heckles. Caught, gutless-

'You've got your Viking. Trained her up. You're all the fucken same.'

You hear him turn. Pull the sheets roughly. Listen to the cotton threads take his shape.

You move slowly back to your room.

Wait. Implore the dark. Compose your physiology.

The goats are quiet. Your father is anaesthetised. Your mother is dead tired. Your brother sleeps defensively. You read the settled badland.

Certain, you close your door softly. Turn into your asylum. Breathe.

Now you can act your age. You grab an Archie comic. Flop on your bed. Flick to the middle.

Wonder what a sea monkey is.

-II

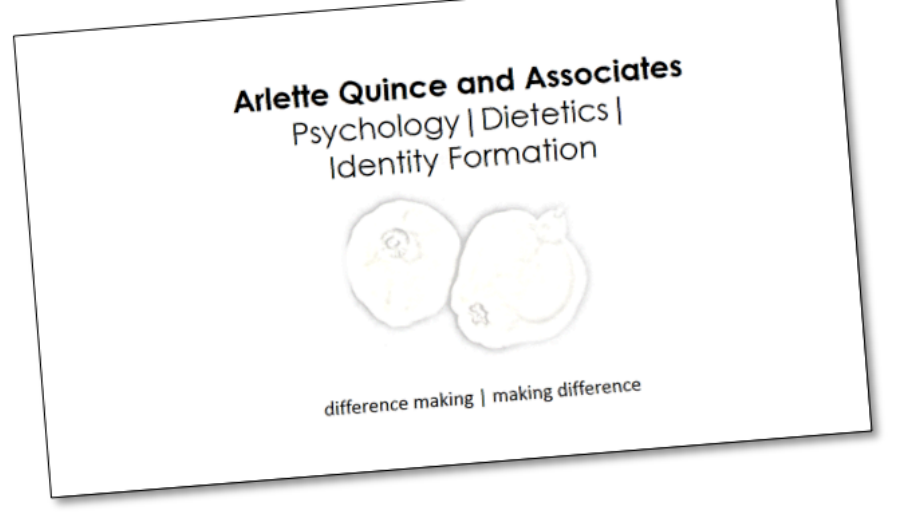


Friday, 8:55pm

It's like saying that quinces are pretty. They're not. What they are is decent. Not trying to be supermodel peaches. Quinces make great jam is the point. They wait in a candid way for the transformative process. That's how nostalgia is for me. I think you have to be in the mood. And I'm not. Feeling it. Touching it. Smelling it. The jar is empty and I ran out of labels.

Friday, $10.32 \mathrm{pm}$

I have a headache trying to make jam. I just noticed that there are two small children asleep in the house where I'm living. I wonder where they've come from. I don't think I'm their mother but I'm not sure. The boy and girl are both blonde and I'm not. Although that doesn't mean anything. Genes can play tricks. I need to take some paracetamol to fool my pain receptors. I'll be right back.

\section{Saturday, 11.50am}

Those kids aren't mine. I checked my stomach just in case I was abusing them inadvertently. I'd feel terrible if I should feel love for them and I didn't. They looked sweet while they were sleeping and when they saw me this morning they used my name and smiled. That's a sign of something. It made me look for other signs. Markers that might help.

I sat down at the desk and looked at the detritus. Whoever this is seems to read a lot. They like texts. All kinds. I pick one up. Reveries of a Solitary Walker by Rousseau. Inside is crammed a copy of a poem by Oodgeroo Noonuccal, Dreamtime. I read about her 'talk-talk place.' Scribbled at the bottom of the page 'Placeless poetic - "wrenched out of the natural order"' it says. Then further on '...intensification of now and multiple reals-nostalgic ancestral marrow. You must edify untelling.' Nearby are still other forms. Kevin Gilbert's People are Legends. And a carved emu egg perched on a copy of A Confederacy of Dunces. John Kennedy O'Toole. I touch the cover. There's a picture of a behemoth in a hunting cap on the front.

'Ahh. It's good that you are trying to remember,' I hear a man's voice behind me. 'Maybe something at your desk will trigger you.' 
His timbre seems familiar. He moves his body closer and I turn. Smiling kind shaven face meets me. He leans in and kisses me. On the mouth. It's succulent and intimate. His rough skin scratches my face. I don't like the sensation at all. I can't say anything because I think this man is supposed to be my husband, but I'm not sure. I really don't want his complication. This maybe spouse continues to talk to me. I'm feeling flooded. Marooned.

Saturday 3.34pm

My husband (he said he is) told me many things I can't recall. That I'm Aboriginal. That I enjoy grizzly, perilous sex. That I am in a constant state of libidinal requisition and genital awe. I can't find truth in this, if the truth be known. Surely my body could remember despite itself and be aroused by the avowal. Instead, all my organs invert at the thought. It's obscenely herbaceous.

He says I have motifs. Quinces. And bread. I can see the sense in appraising the packet to know what to expect inside. People are cartons with bewildering interiors. Depths that can striate and damage. We all eat what we read. So kind cautions are critical. I'm not sure of this thematic derivation, but it appeals to my current thinking. And I feel educated with a disciplined mind. Whoever I am. Which reminds me. My husband (I think he's lying) says that I'm a shower-writer. I think he means like singing. It sounds okay to my ear but the real trial is the bigger eavesdrop beyond the grout. Over the last few days I have found myself thinking like a writer. I like the idea that I might write like a thinker. I can't be sure so I'll stick to a cubicle jingle for now. It could work out that I'm tone deaf in the end.

Saturday, $4.01 \mathrm{pm}$

Something truly awful happened when I was a child. Distilled to a finitude of 'itness'. It happened. This is what my husband was telling me. It happened to me and I have been remembering to forget ever since. My efforts have been stellar in attenuating the trauma. I walk around like clarified butter, having separated the sediments and existing only in one anchored form-the present. Being not there is safe. But maybe I've gone too far and become overly-excellent in my gaps. I think this shielding device is melting a little at room temperature, and this man (queerly he seems to have breasts) is complaining about my shapeless fake-tan orgasms. So being here is bothersome. I have to go. It's him again. 


\section{Saturday, $11.29 p m$}

I'm sitting at my desk. The clumpy geography intrigues me like a tourist. I reach to touch the etching on the emu egg. On one side is an Ancestral Being. On the other, an image of a Western female. I feel a sudden smack. A song line friction noting distant rhythm. Undulating dissonance. Two-world woman both. Give from mission friend. Shy tell. See in eye not look. No place every nothing. Always pelican laugh.

I feel something. Of myself. Am touched by something. Of myself. Smell meat pies in the boot of a car when I look at that egg. Still scented, I catch John Kennedy O'Toole in the corner of my nostril. I'm in New Orleans in a spicy brassy Creole precinct. Next in a trouser house. Then in a wretched apartment with a large and lazy man-child and his mauve mother. I remember I love this anti-hero and the picaresque form. I wanted to go there. To understand the Jonathon Swift genius and 0'Toole's suicide. So much I wrote a one-act play about it. The Noun Factory An Act in One Play, I called it.

I remember. Longing. Sickness. I remember it. It. Happened.

\section{Sunday, 9.34am}

I think I'm not comfortable with the involuntary. I choose to not remember. But those visceral clutches play havoc with my plumbing. Jam me up like an ugly fruit. It seems from my melancholy I have always wanted to be not here or there. Placeless. I can only say I need survival over nostalgia.

To edify untelling.

$$
\text { -IV }
$$

Me: $\quad$ Hi. It's me.

Them: Hello you. How is everything?

Me: $\quad$ Not so good.

Them: That's too bad. What happened?

Me: I wrote entries in that diary like you prescribed.

Them: Then what happened?

Me: $\quad$ I re-read them in my inner ear.

Them: $\quad$ And what did you hear? 
Me: $\quad$ Too many lies.

Them: Have you always told stories?

Me: I've always told a truth.

Them: What kind?

Me: $\quad$ The safe kind.

Them: Was it helpful?

Me: $\quad$ No. I'm badgering myself into perjury. And wasting time re-packing.

Them: Do you think you need a distraction?

Me: I enrolled in a PhD.

Them: How's that going?

Me: It's difficult.

Them: Why is that?

Me: $\quad$ I find the form prickly.

Them: How so?

Me: It makes the point go 'ouch'.

Them: What is the point?

Me: $\quad$ It only wants part of me.

Them: Withholding can be healthy.

Me: $\quad$ It's become a splintered, irreconcilable tale inside an ugly fruit I cannot peel.

Them: $\quad$ There seems a gap between you and it.

Me: $\quad$ There is a gap between me and other eyes. I hate the master-gaze of efficacy. It doesn't feel.

Them: What do you not want?

Me: $\quad$ To be a cartographic reading diagnosed to graduate.

Them: What do you not need?

Me: $\quad$ Absence in the territory.

Them: What can you do differently?

Me: $\quad$ Show more me.

Them: How will you do it?

Me: I'll have to find a way. 
Letter to a PhD

'To them', I said, 'the truth would be literally nothing but the shadows of the images'

Plato, The Republic, Book VII (the 'cave allegory')

Dear Methodology Chapter-,

It's cagey in here. I don't want to make onions without end, so we have to be clear about truth. There's a distorted dance of selves going on.

Can we stop? Be still? Act wireless for now?

I need to confess you unsettle me. I'm so dazed and unearthed I've become urgent. What I had wanted was a thoughtful, disciplined frisson in learning you. Extending me. Theory with a truth of self seemed easy. Radiating comfort. Is that not the compelling real when there is everywhere to go? And you seemed to offer an expansive terrain: a bounded rigour dilated with creative excess.

But smugly, senseless me had deliberately forgotten this is intimate.

Your expectant edges cut my spine. Each encounter at your boundaries like serrations. You forced my personhood to recoil. So every time truth tried to surface, I had to mobilise poetic tactics to sink the revelations. And make bandages of metaphors. It has been a constant re-production of the patterns of pursuit/retreat; of show and tell. Exposure similitudes. Those verify/deny duplicities, all variants of fear.

I have understood the jostling. Remained despite the nettle. And can say with gripping decency I have been honest wherever I have scurried.

I'm anxious though.

It's what I have implied inside your implications, where so much meaning circulates regardless of what is meant. I don't like this fraying insight. Or the sense that I am a simultaneous actor rehearsing for a part in knowledge.

I used to perform stand-up comedic monologues. I knew I was making styled sets of other selves from slippages to speak to the cracks I had grown up in. They were shards of a master text. Clumsy disguises of a staged expose. But I have always 
found the captive self an uncomfortable exhibit. I prefer to edit the body on the page. I always have. I think because my family seemed absurdly fictional. True things seemed invented. It was a strange inversion. Words seemed more real to me, more normal. Even as a tiny ugly fruit with crayons

It's funny. Quinces have inhabited my life since I can remember. Everything my father did not like received his sententious 'Lick my quince'. When my mother confronted him with his own reflection, he told the truth to lick his quince. If my brother or I required some normal range of fathering, the inconvenience to his drinking told us to lick his quince.

Ironic. Paris gave Aphrodite a quince as a mark of love.

A fruit displaced became a placeless place. For us. Maybe families are heterotopias after all. Mine seemed so. I remember feeling so much not like them. Not knowing why. I looked like them, so couldn't doubt that I was marked to fit somehow. But I felt like I had been hatched from a potato somewhere else. I didn't speak like my family; didn't think like my family. Could only find sameness in the reductive prowess of my father and the unifying awfulness of his abusive oppression.

I told a friend about this once. She said that I was a strange genetic graft. Something hybrid, an unexpected yield. I think it was supposed to be affirming. It felt like quince licking to me. So I was silent after that. Just kept rehearsing.

But now I act.

I cannot be limited by your straight lines anymore, or the arguments that you don't live: mapping me; mapping them. You make words into chairs on a bus tour. It is a space where bodies cannot stand or walk in earth to feel or understand beneath the traces you impose. What I want is a place to experience what is possible. But to make lies of 'what is' would be pointless. I cannot paint in disremembered strokes. Or ignore the fault lines in showing/telling of reduction. For so long as a child, I wanted to know what I wasn't, to explore and shelter in the places that could not be my father. Being told I should be proud of 'being blackfulla' as I watched my mother bleed. As an adult perhaps I have found false security in concepts; an inert space of resistance or immunity.

Painfully. So slowly. Suddenly we're here.

My father an Elder. 
Me an Academic.

All of us trapped in sediments of knowledge engaged in an uncomfortable smack of knowing.

Certain in the uncertainty of how we arrived. Hanging from the limbs of ghosts, in a tricky bond of bruising. Sharing ancient weather.

It is a point of cultural truce.

Finally, an authentic self is all I seek. I don't know where it lurks. Perhaps somewhere where the schisms are companions. A strategy of encounter where the writing/reading meets.

It feels good to leak.

To spill the truth, although I still prefer to supplant than claim. Finally all this textual scat is unified and I can focus on a sole despair of self.

Bare or bear. Without consent. More than faithful to my words.

Thank you for your clarifying precinct.

me

Gabrielle Lorraine Fletcher is a Gundungurra woman from the Blue Mountains of New South Wales. She is currently an associate lecturer and $\mathrm{PhD}$ (Aboriginal Studies) candidate at the Wollotuka Institute, University of Newcastle. Her thesis explores the possibilities of authentic Aboriginal self-hood within the redactive spaces of post-colonial theatres. She has been previously published in Cultural Studies Review and Salt: The International Journal of Poetry and Poetics. $<$ Gabrielle.Fletcher@newcastle.edu.au>. 